\title{
Strong medicine for French research
}

\section{The medical-research adviser to France's president aims to shift power and money to universities.}

Arnold Munnich has been scientific adviser for medical research and health to French president Nicolas Sarkozy since 2007. A paediatric geneticist at University Paris Descartes, he heads the Jean Frézal Centre of Medical Genetics at the Necker Hospital for Sick Children in Paris, an institute run jointly with INSERM, the national biomedical research agency.

\section{How did you come to be chosen as a presidential adviser?}

It was serendipitous. Back in 2000, I wrote a provocative article in the newspaper $L e$ Monde, criticizing the hype around the sequencing of the human genome. As a clinical geneticist on the front line of treating children with genetic diseases, I knew that the genome is ultimately just a long list of nucleotides, and that we still have a long way to go to understand it - that this was not going to change the life of the patient immediately.

Sarkozy, who was at that time mayor of Neuilly-sur-Seine in the western suburbs of Paris, happened to read the article and invited me to a breakfast meeting. He was extremely concerned about the ethical issues and health effects of genetics research, and also its possible negative consequences. I invited him to spend a day with us at the lab and hospital, which he did. Subsequently, we kept in touch and, during his presidential campaign in 2007, he occasionally asked me for advice. After the election he called me and said, "Arnold, do you want to be my adviser for medical research?” I told him, "Are you kidding? You know my life, and how busy I am already. I have no political ambitions, and am very happy in my job here." But he insisted that I could do more. So ever since, although I've kept the same hours at the hospital, I now work at the Élysée Palace from seven to nine in the morning and from six to nine in the evening.

\section{What is your main role as adviser?}

I mostly focus on reforms of the funding and organization of French biomedical research. France historically had weak universities, and to remedy this the government created large national research agencies before and after the Second World War. These controlled every aspect of research - they designed the programmes, funded them, carried them out and evaluated them.

But this centralized monolithic structure, inherited from the past, has its limitations. Sarkozy has decided that the French scientific system will instead pursue the model that has been so successful in other highly developed nations, with powerful research universities at its centre. One of his first actions after being elected in 2007 was to pass a law giving the universities autonomy from centralized state control. They can now manage their own land and buildings, entirely handle their own budgets and have some flexibility to set researchers' salaries as they see fit, instead of being tied to rigid national salary scales - this gives them more openness and freedom to retain, or to attract, the best researchers.

\section{Are the universities ready for this change?} The crucial task is to identify and support the most competitive research universities. Not all teaching universities can also be first-class research universities, so we are encouraging consolidation and mergers.

In 2008, we launched 'Operation Campus', a €5-billion (US\$6.2-billion) project to restructure and refurbish a select few universities. And as part of the $€ 35$-billion package of the grand emprunt, or 'big loan', announced by the president last December to boost the country's longterm competitiveness (see Nature 462, 838; 2009), €11 billion will go to the universities. There will be competition for the money, with five to ten of the best campuses receiving billion-euro endowments.

\section{Where does this leave the research agencies?}

They now pilot national strategy and fund research, much like research councils. But universities have become the main operators, in charge of organizing their own research strategies. That has been accompanied by a marked shift away from the dominance of recurrent research funding, where the agencies funded labs on a rolling basis, to one where individual labs compete nationally for funding on the basis of grant proposals for projects - with the major player here being the National Research Agency, based in Paris, which was created in 2007 and has a budget of $€ 850$ million this year. Independent evaluation has also been added outside of the agencies, with the creation in 2007 of the Agency for Evaluation of Research and Higher Education in Paris.

\section{An evaluation of INSERM in 2008 recommended a fusion of life-science research across the agencies. How far has this come?}

The panel said that INSERM should be the lead agency for biomedical research, and fold in or absorb much of the life-science research done elsewhere, including that at specialized agencies for AIDS, cancer and other research. In 2009, we created the National Alliance for Life and Health Sciences, an association of eight bodies including INSERM, the National Centre for Scientific Research, the Pasteur Institute and universities that will coordinate research on specific themes across all these agencies. Eventually we would like to see even further consolidation.

\section{What about clinical research, where France is far weaker than the United Kingdom, for example?}

The grand emprunt will help here. France has 32 university teaching hospitals, but they are more focused on teaching and care and less on research than their UK or US counterparts. We aim to upgrade five university teaching hospitals to centres of excellence with a focus on research. A long-standing bad habit in France has been to seek to spread funding evenly, but this only reduces effectiveness. So we want to fund just a few centres of excellence, those that are most open to reforming their practices to improve research. Overall, reforms of research are moving fast - faster perhaps than mentalities. Interview by Declan Butler.

\section{Correction}

The News Feature 'Illuminating the brain' (Nature 465, 26-28; 2010) contained an incorrect statement regarding the experimental work of Philip Sabes. In fact, no needles were broken during the primate experiment. 